also apply to man, the intermarriage of congenital deaf-mutes through a number of successive generations should result in the formation of a deaf variety of the human race." For example: let some of the congenitally deaf marry congenital deaf-mutes; then let some of their deaf children marry congenital deaf-mutes, and some of their deaf children marry congenital deaf-mutes, etc., then the percentage of deaf children born of such marriages will increase from generation to generation, until finally all, or nearly all, of the children will be born deaf. The families of which this would be true would then constitute a variety of the human race in which deafness would be the rule instead of the exception.

Now, Mr. Jenkins is greatly exercised over the fact that all the distinguished scientific men whose opinions are quoted in the little pamphlet entitled " Facts and Opinions relating to the Deaf," admit this theory to be true. He gets over the difficulty, however, when be discovers that these gentlemen all belong to a scientific association of which I also am a member; and he says, "A member of their own fraternity has asked them their opinion on a theory of his own formulating; and, in complimentary deference to a great name, they have indorsed the theory."

I need make no further comment upon this than to say that the "fraternity" refers to no less a body than the National Academy of Sciences; and that the gentlemen who are so willing to subordinate their real opinions out of complimentary deference to me are Professor Edward D. Cope, Professor Alpheus Hyatt, Dr. H. P. Bowditch, Professor William H. Brewer, Professor Simon Newcomb, and Professor W. K. Brooks.

But to all his numerous mistakes Mr. Jenkins puts a climax when he credits the above theory to me. Such an error might be pardonable in one not connected with the Hartford School for the Deaf; but it is surely unpardonable that Mr. Jenkins should not know the author of the theory to have been the principal of the very school in which Mr. Jenkins himself is an instructor.

In my "Memoir" (p. 196) I quote the words of the late Rev. W. W. Turner, as follows: "It is a well-known fact that among domestic animals certain unusual variations of form or color which sometimes occur among their offspring, may, by a careful selection of others similar and by a continued breeding of like with like, be rendered permanent, so as to constitute a distinct variety. The same course adopted and pursued in the human race would undoubtedly lead to the same result. . . . Early consideration of philanthropy, as well as the interests of congenitally deaf persons themselves, should induce their teachers and friends to urge upon them the impropriety of intermarriage" (from a paper upon "Hereditary Deafness," published in 1868; for further references see my Memoir, p. 196).

The above is the theory for which I have so often been denounced. But the statistics of the "Memoir," to which alone I can lay claim, and which have led me to fear that a deaf variety of the human race is actually in process of formation in America, have never been seriously questioned.

Many statistics have since been collected by deaf-mutes themselves, and by their teachers, to show that there is no cause for alarm; but their figures all demonstrate that the percentage of deaf offspring born of deaf-mute intermarriages is many times greater than the percentage of deaf offspring born of the marriages of those who hear.

The testimony of the present principal of the Hartford School, Mr. Job Williams, is specially strong upon this point, although it is adduced to sustain the opposite contention (see Facts and Opinions, pp. 42-50).

In view of these facts, we cannot but note with alarm that many of the most prominent teachers of the deaf in America advocate the intermarriage of deaf-mutes. Dr. Philip G. Gillett, superintendent of the Illinois Institution for the Education of the Deaf, says (Facts and Opinions, p. 53), "I do not discourage the intermarriages of the deaf, as they are usually more happily mated thus than where one of the parties only is deaf. The deaf need the companionship of married life more than those who hear, and it is a gross wrong to discourage it."

Dr. Gillett is probably the oldest teacher of the deaf in America, -not oldest in years, but oldest in service, -and he is looked up to as a guide by very many in the profession.
Much good might arise from a comparison of views between Dr. Gillett and those scientific gentlemen who have given most attention to the subject of heredity. May I ask him, through the columns of Science, what would be his advice in such a case as the following?-

A young man (not a deaf-mute) became deaf in childhood while attending public school. He has one brother who is a deaf-mute, and another who can hear. Two others of the family (believed to be hearing) died young.

The father of this young man was born deaf in one ear, and lost the hearing of the other subsequently from illness. He had a congenitally deaf brother who married a congenital deafmute and had four children (three of them congenital deaf-mutes).

The mother of the young man was a congenital deaf-mute, and she also had a brother born deaf.

The paternal grandmother of the young man was a congenital deaf-mute, and she had a brother who was born deaf. This brother married a congenital deaf-mute, and had one son born deaf.

The great-grandfather of this young man (father of his paternal grandmother) was a congenital deaf-mute; and he was, so far as known, the first deaf-mute in the family.

Thus deafness has come down to this young man through four successive generations, and he now wants to marry a congenital deaf-mute.

The young lady has seven hearing brothers and sisters, and there was no deafness in her ancestry, but she herself is believed by ber family to have been born deaf.

Dr. Gillett must not think that this is a purely hypothetical case, for it is not. The parties are engaged, but the marriage has not yet been consummated, and I know that Dr. Gillett's advice would have weight with the young people.

The teacher of the young lady has been consulted, and she feels her responsibility deeply. Her heart is with the young couple, and she desires their happiness, and yet her judgment is opposed to the union.

Will Dr. Gillett tell us what his advice would be in such a case? Washington, D.C., Sept. 1. Alexander Graham Bell.

\section{Treatment of Snake-Bites.}

IN Science of Aug. 22, 1890 (p. 107), it is stated that Professor Kaufmann strongly condemns the use of large quantities of alcohol in the treatment of snake-bites, as he thinks it paralyzes and depresses the nerrous system.

Now, this paralyzing and consequent depressing effect of alcohol in snake-bites is just wherein its medicinal or remedial value lies ; for by this paralyzing effect, tissue change and general metamorphoses of both the solids and fluids of the body are retarded, and the reactionary susceptibility of the system is blunted and benumbed; so that the venom is more slowly fed into the system, which is, by the paralyzing effects of the alcohol, rendered less susceptible to disturbing influences. Thus the vis medicatrix naturoe is given more time in which to eliminate, and in smaller quantities, the venom from the ssstem.

This is another striking proof of the truth of the ancient aphorism, "Do not allow your theories to interfere with your practice."

Austin, Tex., Aug. 26 Q. C. SMITH.

\section{Temperature in Storms and High Areas.}

ONE of the first practical discussions of this question was published in 1886 by M. Dechevrens, of Zikawei, China, and a translation of this paper will be found in the American Meteorological Journal for August, 1886. An independent investigation of this same question was carried on in this country before the above publication, the results of which will be found in the journal quoted above for October, 1887. The latter study showed that the temperature fluctuations were almost exactly the same, and had the same phases, both at the base and summit of high mountains, which was exactly opposite to the results obtained by $M$. Dechevrens. Dr. Hann of Vienna espoused the cause of M. Dechevrens, and tried to show that the observations at Sonnblick indicated the 